\title{
ЗАПРОВАДЖЕННЯ КРЕДИТНО-МОДУЛЬНОЇ СИСТЕМИ У ПРАКТИКУ РОБОТИ МЕДИЧНОГО ФАКУЛЬТЕТУ ТДМУ
}

\author{
І. О. Крицький, П. В. Гощинський, Г. А. Крицька
}

ДВНЗ “Тернопільський державний медичний університет імені І. Я. Горбачевського МОЗ Украӥни”

\section{INTRODUCTION OF CREDIT-MODULAR SYSTEM IN PRACTICE OF MEDICAL FACULTY OF TERNOPIL STATE MEDICAL UNIVERSITY}

\author{
I. O. Krytskyi, P. V. Hoshchynskyi, H.A. Krytska \\ SHEI "Ternopil State Medical University by I. Ya. Horbachevsky of MPH of Ukraine"
}

\begin{abstract}
У статті проаналізовано п'ятирічний досвід впровадження кредитно-модульної системи на медичному факультеті, де здійснюється підготовка фахівців за спеціальностями “Лікувальна справа”, вивчено ставлення основних суб'сктів педпроцесу до організації навчання на засадах Болонської системи, визначено переваги нових технологій організації навчального процесу та програми і їх причини.
\end{abstract}

The article adduces the five-year experience of credit-modular system at the Medical Faculty, which trains specialists in "Medicine", the attitude of the main subjects of educational process to provide training on the principles of the Bologna system, identified the benefits of new technologies of the educational process and programs and their causes.

Вступ. Основною стратегічною лінією розвитку вищої освіти в Україні є реалізація основних положень та принципів Болонської декларації, що забезпечує інтеграцію вищої освіти в єдиний європейський освітній та науковий простір.

Першочерговою метою і завданням Болонської декларації виступає впровадження нової методології та технології навчання - кредитно-модульної системи організації навчального процесу $[1,3]$.

На медичному факультеті кредитно-модульну систему організації навчання запроваджено з 2005 року, що відбулося за рішенням вченої ради університету. У 2005-2006 навчальному році студенти I курсу почали навчатися за новою системою і так щорічно, поступово було здійснено повний перехід до навчання за кредитно-модульною системою. Нині навчання за новою системою організації відбувається на шести курсах, на освітньо-кваліфікаційному рівні: “лікар-спеціаліст”. ТДМУ отримав від МОЗ України дозвіл на проведення експерименту щодо реформування навчального процесу на засадах Болонської декларації.

У зв'язку з цим було розпочато активну роботу з реорганізації процесу підготовки фахівців. Першим кроком на цьому шляху була розробка нормативних документів, які мали регулювати діяльність суб'єктів навчального процесу - викладачів та студентів, а саме: Положення про кредитно-модульну систему організації навчального процесу в університеті та Положення про оцінювання навчальних досягнень студентів; створення інформаційних пакетів та визначення форми індивідуального плану для студентів з даної спеціальності.

Основна частина. Організація навчального процесу на факультеті упродовж останніх п'яти років дає підставу визначити певні переваги в підготовці фахівців за новими підходами, і окреслити проблеми, пов'язані із запровадженням кредитно-модульної системи.

Застосування кредитно-модульної системи навчання - це, передусім, пошук нових навчальних технологій, які б забезпечили високу якість вищої освіти та міцне засвоєння максимальної кількості знань при мінімальних витратах часу. Вона передбачає визначення трудомісткості навчальної праці студентів у кредитах, структурування навчального матеріалу за модулями, підсумковий модульний контроль, рейтингове оцінювання навчальних досягнень студента 3 даної дисципліни.

Для полегшення і оптимізації праці викладача у нашому ВНЗ запроваджена локальна комп'ютерна мережа, створені спеціальні сайти для кожної спеціальності з відповідних фахових дисциплін для кожного студента, запроваджено комп'ютерне тестування, яке має переваги щодо збереження часу сту-

(с I. О. Крицький, П. В. Гощинський, Г. А. Крицька 
дента та викладача, і об'єктивного оцінення знань студентів.

Серед головних преференцій кредитно-модульної системи організації педпроцесу студенти відзначають, по-перше, можливість вчасно скласти змістові модулі через їх подрібненість і докладну алгоритмізацію (в середньому 42 \%); по-друге, систематичність і послідовність в отриманні знань (в середньому 23 \%); можливість підвищити свій рейтинг за рахунок додаткових завдань (35 \%); студентам найбільш сприятливе поле для успішного і своєчасного засвоєння обраних навчальних дисциплін у кредитних вимірах [2].

Реорганізація навчального процесу на факультеті розпочалася $з$ переопрацювання навчальних планів та робочих програм усіх дисциплін, введення нової системи залікових одиниць - кредитів та модулів. Значна увага надавалася переопрацюванню програм усіх дисциплін. Навчальний матеріал було структуровано за кредитами та модулями. Відсутність централізованих методичних рекомендацій щодо форми робочих програм, їх структури, принципів побудови, привела до пошуку та вироблення в університеті власного підходу.

Перебудова програм за новим принципом мала позитивний ефект, оскільки дозволила чітко визначити обсяг навантаження на студентів, систематизувати їх самостійну роботу. Такий обсяг матеріалу полегшує опанування ним, дає можливість ретельніше розібратися у складних питаннях, отримати необхідні консультації викладача.

Перебудова навчального процесу стимулювала викладачів до активізації роботи із вдосконалення i створення навчально-методичного забезпечення. Було розроблено єдину форму та структуру змістового модуля, яка містить цілі його вивчення; інформацію про нарахування рейтингових балів; стислий зміст лекцій; плани та методичні рекомендації до семінарських занять; питання та рекомендації до самостійної роботи; засоби контролю за даним змістовим модулем; завдання для самоконтролю.

\section{Література}

1. Болюбаш Я. Я. Організація навчального процесу у вищих навчальних закладах / Я. Я. Болюбаш. - К. : ВВП "Компас", 1997.-64 c.

2. Освітні технології : навчально-методичний посібник / [О. М. Піхота, А. 3. Кіктенко, О. М. Любарська та ін.] ; за ред. О. М. Піхоти. -К. : А.С.К., 2001.-256 с.

3. Перспективні освітні технології : науково-методичний посібник / за ред. Т. С. Сазоненко. -К. : Гопак, 2000.-560 с.
Найбільша увага приділяється створенню електронних варіантів методичного забезпечення. Слід зазначити, що усі ці матеріали знаходяться на сайті університету і мають вільний і зручний доступ для кожного студента у будь-який час [4].

На нинішньому етапі в зв’ язку з наявністю потужностей видавництва “Укрмедкнига” в більшості надруковано, а частково здійснюється робота з підготовки до друку підручників з усіх спеціальностей. Кредитно-модульна система - це також перехід до принципово нової системи оцінювання навчальних досягнень студентів - рейтингової, яка грунтується на об'єктивнішому оціненні навчальних досягнень студента, ніж традиційна система. Вона передбачає перевірку якості засвоєння теоретичного і практичного матеріалу кожного модуля, рівня підготовки студента до кожного лабораторного, практичного чи семінарського заняття; виконання самостійної роботи; використання широкої шкали оцінки знань від 1 до 12. Викладачами кафедр відповідно до робочої програми кожної дисципліни було визначено значущість змістових модулів, розроблено шкалу виставлення оцінок. На їі підставі виставляється семестрова оцінка шляхом переведення балів в оцінку за традиційною національною шкалою та шкалою ECTS [5].

Важливе значення надається поінформованості студентів про зміст навчального процесу, аудиторну та самостійну роботи, критерії оцінювання та розподіл балів для виставлення оцінок. Все це створює передумови для здорової конкуренції у навчанні та виконує як контролюючу, так і мотивуючу функції, спонукаючи студента до постійної роботи протягом семестру.

Висновок. Отже, кредитно-модульна система організації навчального процесу ефективно впроваджена на медичному факультеті, завдяки застосуванню в університеті нових для України європейських методик навчання. Студенти університету на ліцензійних іспитах показують високий рівень знань, що забезпечує на світовому рівні конкурентоспроможність їхніх дипломів.

4. Кредитно-модульна система організації навчання у контексті Болонського процесу в Національному фармацевтичному університеті : навч.-метод. посіб. / [укл. В. П. Черних та ін.]. - Х. : Вид-во НФаУ, 2004. -68 с.

5. Освіта : Тимчасове положення про організацію навчального процесу в кредитно-модульній системі підготовки фахівців. - 2004. - № 8 (5084). 